death-rate did not exceed $20 \cdot 7$ per 1000 , which was 3.9 below the rate in the corresponding periods of the five preceding years; it was also 2.0 per 1000 below the mean rate that prevailed during last quarter in the twenty-eight large English towns. The information bearing upon the notification and isolation of cases of infectious disease shows the result of energetic sanitary organisation carried out with tact, the beneficial effect of which upon the health of the borough cannot well be over-estimated. The calculated deathrate of children under five years of age in the last quarter was 53.0 per 1000 living, ranging in the four registration sub-districts from 33.6 in Broughton to $72 \cdot 9$ in Greengate. Nomore conclusive evidence is needed that the sanitary authority of the borough should look for further health progress in Greengate registration sub-district. We should be glad to see other large towns following the example of Salford in the publication of Quarterly Health Bulletins containing similar statistical information, reflecting in so trustworthy a manner the health of the population.

\section{THE SERVICES.}

Among the officers who left Sawakin in the Jumna on the 17 th inst., sick, was Surgeon-Major J. J. Crean. Staff Surgeon P. A. Hayes and Surgeons Hay and Mander are reported as sick on board the hospital ship Ganges. Amongst the officers who left Sawakin for England on the 15th inst. were Staff Surgeon C. J. Holmes and Surgeon W. C. Beevor. The following officers have left Egypt for England invalided: Surgeon-Major J. Kinahan and Surgeon C. E. Faunce.

WAR OFFICE.--Army Medical Staff: Brigade Surgeon George Langford Hinde to be Deputy Surgeon-General, vice Edward Malcolm Sinclair, M.D., placed on temporary halfpay; Surgeon-Major William Temple, M.B., V.C., to be Brigade Surgeon, vice George L. Hinde; Surgeon-Major James Shand Duncan, M.D., is granted retired pay, with the honorary rank of Brigade Surgeon; Surgeon-Major Charles Wyat Watling is granted retired pay, with the honorary rank of Brigade Surgeon ; Surgeon-Major Edward Harford Lloyd, M.B., is granted retired pay, with the honorary rank of Brigade Surgeon; James B. Clarkson (L.R.C.P. \& S. Edin.), Lieut. 19th Lancashire Rifle Volunteers, has been appointed to a commission in the Reserve of Officers.

\section{Uaxtespandence.}

$$
\text { "Audi alteram partem." }
$$

\section{THE ELECTION OF COUNCILLORS OF THE ROYAL COLLEGE OF SURGEONS.}

\section{To the Editor of THE LANCET.}

SiR,-It may simplify the action of the Fellows at the coming election for Councillors at the College of Surgeons if you will allow me to say that it is neither my wish nor my intention to offer myself for re-election.

I am, Sir, yours obediently,

Carendish-place, W., May 16th, 1885. Jorr ERIC ERICHSEN.

\section{"PNEUMOTHORAX FOR HAMOPTYSIS." To the Editor of THE LANCET.}

Sir,- - In an annotation last week you were good enough to speak favourably of my plan of producing artificial pneumothorax. Will you allow me a brief space to point out some advantages which this plan offers over the method by free incision besides the ones you referred to. By using a fine hollow needle the operation can be done without moxing the patient in his bed, without causing any pain, and without chloroform, therefore circumstances of great moment when the patient is enfeebled by disease or loss of blood. Moreover, the pneumothorax can be induced very gradually, and can be suspended or pushed on a the option of the operator. If it seemed desirable, very considerable pressure could be brought to bear on the lung; on the other hand, if for any reason it were thought advisable, by merely reversing the process, the injected air could be immediately withdrawn, and the status quo ante brought about. Once the chest-wall is incised we lose further control over its mechanism, and cannot undo our operation if for any reason it fails to fulfil our requirements. You justly point out the limited application of such a procedure, and yet if it can be undertaken withouit risk or danger, and if the operation can, so to speak, be undone without any difficulty, it may come to be tried at an earlier stage before adhesions to the chest-wall, solidification or other mechanical causes render the lung incapable of collapsing. Such a plan appears to me thoroughly rational and full of promise; it is but an extension of the principle of physiological rest to a diseased organ incapable of getting rest in any other harmless way. Where there are small cavities or aneurysms it is not improbable that a cure may be obtained in a few cases, for it would bring the walls of such cavities into contact with each other and so promote adhesion between them, and obliteration.

Old Cavendish-street, W., May 18th, 1885 Robert WM. PARKer.

\section{PERSONAL EXPERIENCE OF COCAINE AS AN AN ESTHETIC. \\ To the Editor of THE LANCET.}

SIR,--As I believe I am the first member of the profession who has undergone a serious operation under the influence of the new anæsthetic, I feel that I ought to place my experience on record.

About eight years ago, being then in my sixty-second year, and finding that the sight of my right eye was not so good as formerly, I consulted Sir William (then Mr.) Bowman, who informed me that I was suffering from cataract. Finding my left and best eye failing me considerably during the past autumn and winter, I determined to have the right eye operated upon, and with this object placed myself under the care of Dr. Bell Taylor of Nottingham. As I have always had a strong tendency to squeeze the lids forcibly together on slight provocation, and instinctively resent in an exaggerated degree anything like the impact of a foreign body, even of a drop of water, I fully expected it would be necessary to inhale some general anæsthetic, although I dreaded the possible ill-effects of the vomiting and retching which either ether or chloroform might occasion. I had heard, of course, of the employment of cocaine in order to annul sensation during the removal of foreign bodies from the surface of the eyeball and in other slight operations, but never for one moment expected that it would suffice for the extraction of cataract in a hypersensitive individual like myself. The doctor, however, assured me that I should not feel it, and, to my great surprise, I found that this statement was literally true. The solution of cocaine was applied to my eye three times at intervals of five minutes before the operation, and each step of the operation was explained to me by Dr. Taylor as it was successively accomplished; the preliminary incision was completed without pain, as was also the excision of a small portion of the iris made in the upward direction-a satisfictory answer it appears to me to the query, Does cocaine affect deep-seated parts?

I can truthfully affirm that the whole affair was painless, that the cataract was removed without pain, that I have had very little pain or discomfort since, and can now, little more than a fortnight after the operation, see objects distinctly, make out words of small print, and am improving every day.

You hare had satisfactory evidence of the value of cocaine before, but I venture to think none so conclusive as this which I have now to offer.

I am, Sir, your obedient servant,

Staindrop, Darlington. WM. CoperaND, M.R.C.S.

\section{THE PROSECUTION OF IRREGULAR PRAC-} TITIONERS.

\section{To the Editor of THE LANCET.}

SIR,-It is instructive, after reading the opening speech of Sir H. Acland in re the punitive powers of the General Medical Council, to turn to the daily papers to see how well the Incorporated Law Society protects the interests of solicitors. Hardly a day passes without one finding that a prosecution of some unqualified legal practitioner has been 